\title{
A méhnyakrák okozta éves epidemiológiai és egészségbiztosítási betegségteher Magyarországon
}

\author{
Mihály-Vajda Réka dr. ${ }^{1,2}$ - Boncz Imre dr. ${ }^{1,2}$ - Elmer Diána ${ }^{1,2}$ \\ Csákvári Tímea ${ }^{2,3}$ - Németh Noémi ${ }^{1,2}$ - Kajos Luca Fanni ${ }^{1}$ \\ Pónusz-Kovács Dalma ${ }^{1}$. Bódis József dr. ${ }^{1,4}$. Kívés Zsuzsanna ${ }^{1,2}$ \\ ${ }^{1}$ Pécsi Tudományegyetem, Egészségtudományi Kar, Egészségbiztosítási Intézet, Pécs \\ ${ }^{2}$ Pécsi Tudományegyetem, Egészségtudományi Kar, \\ Real World \& Big Data Egészség-gazdaságtani Kutatóközpont, Pécs \\ ${ }^{3}$ Pécsi Tudományegyetem, Egészségtudományi Kar, Egészségbiztosítási Intézet, Zalaegerszeg \\ ${ }^{4}$ Pécsi Tudományegyetem, Általános Orvostudományi Kar, Klinikai Központ, \\ Szülészeti és Nőgyógyászati Klinika, Pécs
}

\begin{abstract}
Bevezetés: A méhnyakdaganatok kérdése kiemelten fontos, megoldatlan népegészségügyi probléma. A betegség terhe magas, ami elsősorban az alacsony és közepes jövedelmú országokban élőknél jelentkezik.

Célkitüzés: Elemzésünk célja volt meghatározni a méhnyakdaganatok epidemiológiai és egészségbiztosítási betegségterhét Magyarországon a 2018-as évre vonatkoztatva.

Adatok és módszerek: Elemzésünket a Nemzeti Egészségbiztosítási Alapkezelő (NEAK) finanszírozási adatbázisának 2018. évi adatai alapján végeztük az in situ (D06), a jóindulatú (D26.0) és a malignus (C53) méhnyakdaganatokra vonatkozóan. Az elemzés a NEAK által finanszírozott összes szolgáltatóra és ellátási formára kiterjed. Meghatároztuk az éves betegszámokat, a prevalenciát 100000 lakosra, továbbá az éves egészségbiztosítási kiadásokat betegségcsoportonként és korcsoportos bontásban, valamennyi egészségbiztosítási ellátás tekintetében.

Eredmények: A NEAK 2018-ban 1,276 milliárd Ft-ot (4,7 millió USD; 4,0 millió EUR) költött a méhnyakdaganatok kezelésére. A betegek és a finanszírozás döntő többsége a méhnyak rosszindulatú daganatához kapcsolható. A finanszírozásból a malignus méhnyakdaganatok részesedése 97\%. Ellátási típusonként vizsgálva a legnagyobb kiadási tétel az aktívfekvóbeteg-szakellátásban jelenik meg, éves szinten 763,9 millió Ft, ami az összköltség 59,9\%-a. A 100000 lakosra jutó prevalencia az aktívfekvőbeteg-szakellátás igénybevételi adatai alapján 26/100 000 lakos.

Következtetés: A méhnyakdaganatok kezelésének meghatározó költségeleme az aktívfekvőbeteg-szakellátás. Hazánkban a szervezett méhnyakszürés korszerúsítéseként az új szúrési stratégiát megfelelő finanszírozási támogatással célszerú bevezetni, a szúrővizsgálatoknak, a hozzájuk kapcsolódó további diagnosztikus kivizsgálásnak és terápiának a teljesítményvolumen-korlát alóli mentesítésével.
\end{abstract}

Orv Hetil. 2021; 162(Suppl 1): 22-29.

Kulcsszavak: méhnyakdaganat, betegségteher, egészségpolitika, egészségbiztosítás, finanszírozás

\section{Annual epidemiological and health insurance burden of cervical cancer in Hungary}

Introduction: Cervical cancer is a particularly important, unresolved public health problem. The burden of the disease is high, primarily in those living in low- and middle-income countries.

Objective: Our aim was to determine the annual epidemiological disease burden and health insurance cost of cervical cancer in Hungary in 2018.

Data and methods: Our analysis was made according to the financial database of the National Health Insurance Fund Administration (NHIFA) of Hungary for the year 2018, which covers all service providers and maintenance forms financed by NHIFA. We analysed the in situ (D06), the benignant (D26.0) and the malignant (C53) cervical tumours. The data analysed included annual patient numbers and prevalence of care utilisation per 100000 population furthermore annual health insurance costs calculated for disease and age groups. 
Results: In 2018, NHIFA spent 1.276 billion HUF (4.7 million USD, 4.0 million EUR) on the treatment of patients with cervical cancer. The majority of patients and funding can be linked to malignant cervical cancer (97\%). Acute inpatient care was the major cost driver: 763.9 million HUF $59.9 \%$ of the total health insurance expenditures) annually. The prevalence is 26 per 100000 population based on acute inpatient care data.

Conclusion: Acute inpatient care was the major cost driver. In Hungary, as a modernization of organized cervical screening, it is appropriate to introduce a new screening strategy with appropriate financial support, by exempting screening tests, associated additional diagnostic testing, and therapy from the performance volume limit.

Keywords: cervical cancer, disease burden, health policy, health insurance, financing

Mihály-Vajda R, Boncz I, Elmer D, Csákvári T, Németh N, Kajos LF, Pónusz-Kovács D, Bódis J, Kívés Zs. [Annual epidemiological and health insurance burden of cervical cancer in Hungary]. Orv Hetil. 2021; 162(Suppl 1): 22-29.

(Beérkezett: 2021. január 3.; elfogadva: 2021. január 19.)

\section{Rövidítések}

BNO = Betegségek Nemzetközi Osztályozása; CT = (computed tomography) komputertomográfia; DNS = dezoxiribonukleinsav; EFOP = Emberi Erőforrás Fejlesztési Operatív Program; GLOBOCAN = (Global Cancer Observatory) a rákos megbetegedések globális statisztikáját tartalmazó adatbázis; $\mathrm{HPV}=$ humán papillomavírus; $\mathrm{HR}-\mathrm{HPV}=($ high risk human papillomavirus) magas kockázatú humán papillomavírus; MRI $=($ magnetic resonance imaging $)$ mágnesesrezonancia-képalkotás; NEAK = Nemzeti Egészségbiztosítási Alapkezelő; PET = pozitronemissziós tomográfia; WHO = World Health Organization (Egészségügyi Világszervezet)

A méhnyak rosszindulatú daganata hosszú idő alatt kialakuló, megelőzhető betegség. A rák előtti elváltozások kimutatására alkalmas szűrôvizsgálatok elérhetősége és az elváltozások hatékony kezelésének lehetôsége rendelkezésre áll. Mindezek ellenére a betegség terhe magas, ami elsősorban az alacsony és közepes jövedelmú országokban élőknél jelentkezik, ahol ötször magasabb az előfordulás, mint a magas jövedelemmel rendelkező országokban [1].

Becslések szerint világszerte 570000 megbetegedés és 311000 haláleset következtében a méhnyak rosszindulatú daganata a nók körében 2018-ban a negyedik leggyakrabban diagnosztizált megbetegedés és a negyedik leggyakoribb daganatos halálok volt. Becsült, életkor szerint standardizált előfordulási aránya 100000 nőre vonatkoztatva 13,1 volt világszerte. 28 országban a leggyakrabban diagnosztizált daganat, 42 országban pedig a daganatos megbetegedésekből eredő halálozások vezető oka. Ezek túlnyomó többsége Afrika szubszaharai térségében és Délkelet-Ázsiában található. Az incidencia Szváziföldön a legmagasabb, ahol a nők kb. 6,5\%-ánál kialakul 75 éves kor előtt a betegség. Világszerte a méhnyak rosszindulatú daganatának diagnosztizálásakor az átlagos életkor 53 év, az elhunytak átlagos életkora pedig 59 év $[2,3]$.

Az elmúlt évek incidenciaarányai Európában nem változtak jelentősen. A 2002. évi GLOBOCAN-jelentés szerint a méhnyak rosszindulatú daganatos megbetege- désének gyakorisága Európában 11,05/100 000 nő, míg 2018-ban 11,2/100 000 nő volt. Ez azt jelzi, hogy a citológiaalapú szűroóprogramok elérték a maximális hatást, így az elsődleges szưrővizsgálatot módosítani kell a betegség gyakoriságának további csökkentése érdekében $[4,5]$. A humán papillomavírus (HPV) okozta tartós fertőzés következtében kialakuló megbetegedés megelőzéséért és időbeli felismeréséért végzett HPV-oltási programnak a HPV-DNS-tesztekkel végzett szûrôprogramokba való hatékony integrálása bizonyítottan képes csökkenteni a betegség okozta terheket a világ minden országában. Az Egészségügyi Világszervezet (World Health Organization; WHO) eradikációs programjának célja az átoltottság és a szû́réssel kapcsolatos mutatók javítása, illetve annak elérése, hogy a 100000 nôre vonatkozó előfordulás minden országban kevesebb mint 4 eset legyen $[1,3,6,7]$.

A szúrési program kialakításakor mérlegelni kell, hogy milyen módszer kerüljön alkalmazásra. Az európai és amerikai ajánlások a HPV-DNS-tesztet önállóan mint elsődleges szúrőtesztet ajánlják, és negatív eredmény esetén 5 évente, illetve korosztálytól függően akár 10 évente javasolják az ismétlést [8]. Az európai iránymutatások a citológiatesztet javasolják kiegészítő vizsgálatként minden HPV-pozitív esetben [9-11]. Póka a 2018-as tanulmányában felhívja a figyelmet a hazai méhnyakszúrési rendszer korszerúsítésére, mint a folyadékalapú mintavétel bevezetése és a HPV-DNS-szúrésre való populációs szintủ átállás, ami több országban - köztük Svédország, Nagy-Britannia, Hollandia, Olaszország, Franciaország, Finnország, Norvégia, Kanada, Ausztrália, Új-Zéland már megvalósult [12].

A szưrés késői elvégzése vagy elmaradása növeli a rosszindulatú méhnyakdaganat kialakulásának kockázatát, amelynek kezelése az egyén és a társadalom számára is jelentős terhet jelent $[13,14]$. Az egészségpolitikai intézkedéseknek, mint például a népegészségügyi szúrővizsgálatoknak az elindításához nélkülözhetetlen az adott kórkép betegségterhének ismerete [15]. A kiemelt népegészségügyi kórképek - mint az emlő, a vastag- és végbél, valamint a méhnyak rosszindulatú daganata - 
éves egészségbiztosítási költségeit korábban már vizsgálták hazánkban [16, 17].

Elemzésünk célja volt meghatározni a méhnyakdaganatok epidemiológiai és egészségbiztosítási betegségterhét Magyarországon a 2018-as évre vonatkoztatva.

\section{Adatok és módszerek}

Elemzésünket a Nemzeti Egészségbiztosítási Alapkezelő (NEAK) finanszírozási adatbázisa alapján végeztük el. Adatkérésünket a NEAK adatszolgáltatás keretében teljesítette, többszöri és többkörös egyeztetést követően. Az elemzés az összes, NEAK által finanszírozott szolgáltatóra és ellátási formára kiterjed, beleértve az aktív(benne a kúraszerű és az egynapos) és a krónikusfekvőbeteg-szakellátásokat; a járóbeteg-szakellátást (labor és gondozó nélkül); a laboratóriumi ellátást; a komputertomográfiát (CT); a mágnesesrezonancia-képalkotást (MRI); a pozitronemissziós tomográfiát (PET); a gondozóintézeti gondozást; az otthoni szakápolást; a betegszállítást; a mentést; a háziorvosi ellátást; a tételes elszámolás alá eső, egyszer használatos eszközöket, implantátumokat, gyógyszereket és nagy értékü mütéti eljárásokat; a gyógyszerek és a gyógyászati segédeszközök ártámogatását. A vizsgált időszak a 2018. év volt.

$\mathrm{Az}$ adatok a Betegségek Nemzetközi Osztályozása (BNO) 10. revíziója szerinti bontás alapján kerültek leválogatásra. Ez a méhnyakdaganatok esetében a méhnyak rosszindulatú daganata (C53), a méhnyak in situ carcinomája (D06) és a méhnyak jóindulatú daganatai (D26.0) szerinti BNO-kódokat jelentette.

A méhnyak hámeredetû jóindulatú daganatai közül a leggyakoribb a polypus endocervicalis, a cervixcsatorna külső nyílásában kialakult borsónyi, babnyi vérzékeny képlet, amelynek etiológiája ismeretlen. A kötőszöveti eredetú jóindulatú tumorok között a leggyakoribb a leiomyoma, amely izoláltan ritkán, többnyire a méhtest leiomyomáival együtt jelentkezik. Ezek mellett ritkán a méhnyak szöveteiből fibroma is kialakulhat [18].

A méhnyakdaganatok ellátására fordított egészségbiztosítási költségek összesítésekor az aktív- és krónikusfekvőbeteg-szakellátás tételeit a 3. kódolási pozíció (ápolást indokló fódiagnózis) alapján határoztuk meg. A tételes ellátási formán belül nem jelentettek betegadatokat, a mentés esetében pedig nem álltak rendelkezésünkre költségadatok.

A betegségteher-számítások során meghatároztuk a vizsgált kórképek éves betegszámait és az éves egészségbiztosítási kiadásokat. Értékeltük a költségek megoszlását az egyes kórképek esetében, s ennek alapján megállapítottuk azok jellemző ellátási formáját. A költségek megoszlásának értékelését korcsoportos bontásban is elvégeztük. Ezt követően meghatároztuk a 100000 lakosra jutó igénybevételi prevalenciát a különböző ellátási formákra vonatkozóan. A prevalenciaszámítást a Központi Statisztikai Hivatalnak a magyarországi lakónépességre vonatkozó 2018. évi adatbázisa alapján végeztük. Az EUR-ban, illetve USD-ban megadott adatokat a Magyar Nemzeti Bank 2018. évi éves átlagárfolyamán számoltuk át EUR-ra $(318,87 \mathrm{Ft} / \mathrm{l}$ EUR), illetve USD-ra $(270,25 \mathrm{Ft} / \mathrm{l}$ USD).

A NEAK egyedi adatokból aggregált adatokat szolgáltatott számunkra a saját adatvédelmi szabályainak megfelelően. Etikai jóváhagyás a jelen kutatáshoz nem volt szükséges.

A magyar egészségügyi és népegészségügyi rendszer felépítésének, múködésének és finanszírozásának részletes leírása máshol megtalálható [19-26].

\section{Eredmények}

A méhnyakdaganatokhoz bejelentett, 2018. évi aktívfekvőbeteg-szakellátás és járóbeteg-szakellátás betegszámait, valamint az egészségbiztosítási költségeket és azok megoszlását az 1. táblázat összegzi betegségcsoportok szerint. A betegek (aktívfekvőbeteg-szakellátás: 1307 beteg; járóbeteg-szakellátás: 5207 beteg) és a finanszírozás (1,238 milliárd Ft) döntő többsége a méhnyak rosszindulatú daganatához kapcsolódik, a legalacsonyabb értékek pedig a jóindulatú daganatok (aktívfekvőbetegszakellátás: 13 beteg; járóbeteg-szakellátás: 126 beteg; 3,3 millió Ft) esetében jelennek meg. A finanszírozásból a malignus méhnyakdaganatok részesedése 97\%, az in situ daganatoké 2,7\%, míg a jóindulatú daganatoké 0,3\%.

A méhnyakdaganatok kezelésére a NEAK 2018-ban összesen 1,276 milliárd Ft-ot költött, ami 4,7 millió USD-nak, illetve 4,0 millió EUR-nak felel meg. Ellátási típusonként vizsgálva a legnagyobb kiadási tétel az aktívfekvőbeteg-szakellátásban jelenik meg, ami éves szinten

1. táblázat |A méhnyakdaganatok egészségbiztosítási betegségterhe (NEAK, 2018)

\begin{tabular}{|c|c|c|c|c|c|}
\hline BNO-kód & BNO-név & $\begin{array}{c}\text { Betegszám (fő) } \\
\text { Aktívfekvőbeteg-szakellátás }\end{array}$ & $\begin{array}{l}\text { Betegszám (fó) } \\
\text { Járóbeteg-szakellátás }\end{array}$ & $\begin{array}{l}\text { NEAK-kiadás } \\
(\mathrm{Ft})\end{array}$ & $\begin{array}{l}\text { A NEAK-kiadás } \\
\text { megoszlása (\%) }\end{array}$ \\
\hline $\mathrm{C} 53$ & A méhnyak rosszindulatú daganata & 1307 & 5207 & 1237571960 & 97 \\
\hline D06 & A méhnyak in situ carcinomája & 152 & 804 & 34645202 & 2,7 \\
\hline \multirow[t]{2}{*}{ D26.0 } & A méhnyak jóindulatú daganatai & 13 & 126 & 3315935 & 0,3 \\
\hline & Összesen & - & - & 1275533097 & 100 \\
\hline
\end{tabular}

BNO = Betegségek Nemzetközi Osztályozása; NEAK = Nemzeti Egészségbiztosítási Alapkezelő 
2. táblázat |A méhnyakdaganatok NEAK-betegségterhe ellátási formánként (NEAK, 2018)

\begin{tabular}{|c|c|c|c|c|c|c|c|c|}
\hline \multirow[t]{2}{*}{$\begin{array}{l}\text { Ellátási forma } \\
\text { (NEAK-kassza) }\end{array}$} & \multicolumn{2}{|c|}{$\begin{array}{c}\text { C53 } \\
\begin{array}{c}\text { A méhnyak rosszindulatú } \\
\text { daganata }\end{array}\end{array}$} & \multicolumn{2}{|c|}{$\begin{array}{c}\text { D06 } \\
\text { A méhnyak } \\
\text { in situ carcinomája }\end{array}$} & \multicolumn{2}{|c|}{$\begin{array}{c}\text { D26.0 } \\
\text { A méhnyak jóindulatú } \\
\text { daganatai }\end{array}$} & \multicolumn{2}{|c|}{ Összesen } \\
\hline & Kiadás $(\mathrm{Ft})$ & $\begin{array}{l}\text { Betegszám } \\
\text { (fó) }\end{array}$ & Kiadás $(\mathrm{Ft})$ & $\begin{array}{l}\text { Betegszám } \\
\text { (fó) }\end{array}$ & Kiadás $(\mathrm{Ft})$ & $\begin{array}{l}\text { Betegszám } \\
\text { (fó) }\end{array}$ & Kiadás $(\mathrm{Ft})$ & $\begin{array}{l}\text { Betegszám } \\
\quad(\text { fó) }\end{array}$ \\
\hline Háziorvosi ellátás & 17428986 & 4128 & 1023784 & 438 & 259293 & 165 & 18712063 & 4731 \\
\hline Otthoni szakápolás & 1082361 & 20 & 0 & 0 & 0 & 0 & 1082361 & 20 \\
\hline Betegszállítás & 42070109 & 320 & 39704 & 4 & 4925 & 1 & 42114738 & 325 \\
\hline Mentés & - & 56 & - & 5 & - & 1 & - & 62 \\
\hline Járóbeteg-szakellátás & 80738789 & 5207 & 4981444 & 804 & 558012 & 126 & 86278245 & 6137 \\
\hline Gondozóintézeti gondozás & 8404759 & 1288 & 832531 & 175 & 78254 & 5 & 9315544 & 1468 \\
\hline Laboratóriumi ellátás & 4178506 & 1631 & 250642 & 172 & 88895 & 69 & 4518043 & 1872 \\
\hline CT, MRI & 225234742 & 2658 & 7134896 & 97 & 510428 & 11 & 232880066 & 2766 \\
\hline PET & 124520 & 600 & 0 & 0 & 0 & 0 & 124520 & 600 \\
\hline Aktívfekvőbeteg-szakellátás & 742266294 & 1307 & 20128006 & 152 & 1573660 & 13 & 763967960 & 1472 \\
\hline Krónikusfekvőbeteg-szakellátás & 10505220 & 99 & 0 & 0 & 0 & 0 & 10505220 & 99 \\
\hline Tételes elszámolás & 0 & 0 & 0 & 0 & 0 & 0 & 0 & 0 \\
\hline Gyógyszer-ártámogatás & 85344703 & 1690 & 233672 & 54 & 242468 & 43 & 85820843 & 1787 \\
\hline $\begin{array}{l}\text { Gyógyászati segédeszközök } \\
\text { ártámogatása }\end{array}$ & 20192971 & 303 & 20523 & 1 & 0 & 0 & 20213494 & 304 \\
\hline Összesen & 1237571960 & - & 34645202 & - & 3315935 & - & 1275533097 & - \\
\hline
\end{tabular}

CT = komputertomográfia; MRI = mágnesesrezonancia-képalkotás; NEAK = Nemzeti Egészségbiztosítási Alapkezelő; PET = pozitronemissziós tomográfia

763,9 millió Ft (59,9\%). Ezt követi a CT/MRI $(232,9$ millió $\mathrm{Ft} ; 18,3 \%)$, a járóbeteg-szakellátás $(86,3$ millió $\mathrm{Ft}$; $6,8 \%)$ és a gyógyszer-ártámogatások $(85,8$ millió Ft; $6,7 \%)$ költsége. A daganatok típusa szerint a kiadások sorrendjében a méhnyak rosszindulatú daganata (1,238 milliárd Ft), a méhnyak in situ carcinomája (34,6 millió Ft) és végül a méhnyak jóindulatú daganatai (3,3 millió Ft) okozta költségek szerepelnek egymást követve (2. táblázat, 1. ábra).

A különböző ellátási formák igénybevételi mutatói alapján meghatároztuk a méhnyak rosszindulatú daganatának (C53) prevalenciáját. A 100000 lakosra jutó prevalencia a járóbeteg-szakellátás kapcsán a legmagasabb, az igénybevétel adatai alapján 102 beteg/100 000 lakos. Ezt követi a háziorvosi ellátás (81/100 000), a gyógyszerek ártámogatása (33/100 000), a laboratóriumi ellátás (33/100 000), majd az aktívfekvőbeteg-szakellátás (26/100 000) terhe. Az aktívfekvőbeteg-szakellátásban megjelenő betegek prevalenciája korcsoportos bontásban a következőként alakult: a legmagasabb, 47/100 000 lakos érték a 45-54 és az 55-64 éves korcsoportban mutatkozott, majd a 65-74 éves korcsoport következett 100000 lakosra jutó 42 beteggel. A 35-44 évesek között 30, a 75 év felettieknél 22, a 25-34 éves korcsoportban pedig 9 beteg jutott 100000 lakosra (2. ábra).

A méhnyak rosszindulatú daganata (C53) összesített egészségbiztosítási kiadásainak korcsoportos megoszlásánál a legmagasabb kiadást a 45-54 és az 55- 64 éves korcsoportnál találtuk (3. ábra).
Gyógyászati segédeszközök ártámogatása; $1,6 \%$

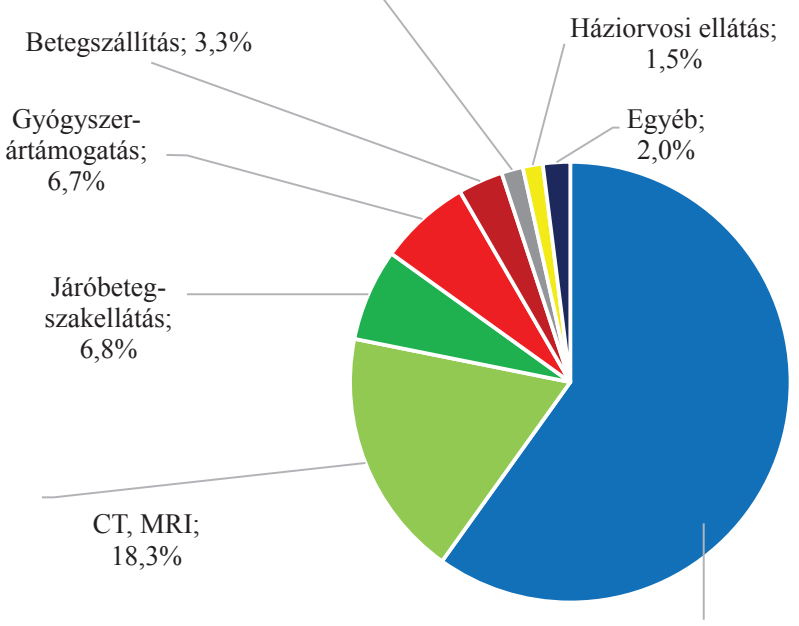

Aktívfekvőbeteg-szakellátás; $59,9 \%$

1. ábra

A NEAK-közfinanszírozás keretében ellátott méhnyakdaganatos betegek egészségbiztosítási kiadásainak megoszlása ellátási formánként (NEAK, 2018)

$\mathrm{CT}=$ komputertomográfia $; \mathrm{MRI}=$ mágnesesrezonancia-képal kotás; NEAK = Nemzeti Egészségbiztosítási Alapkezelő

A méhnyak rosszindulatú daganatának (C53) korcsoportos egészségbiztosítási kiadásait és betegszámait az aktívfekvőbeteg-szakellátás esetében a 4. ábra szemlélteti. Az aktívfekvőbeteg-ellátás jelenti a legmagasabb ki- 


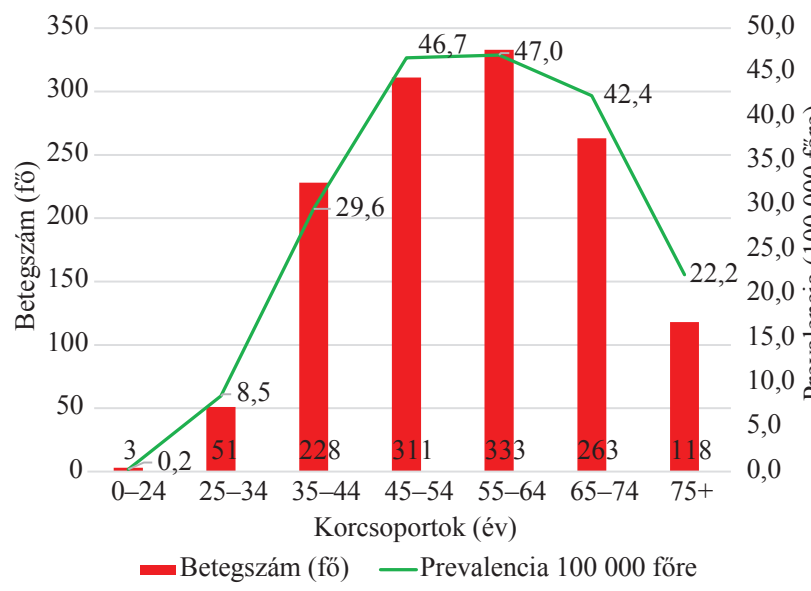

2. ábra
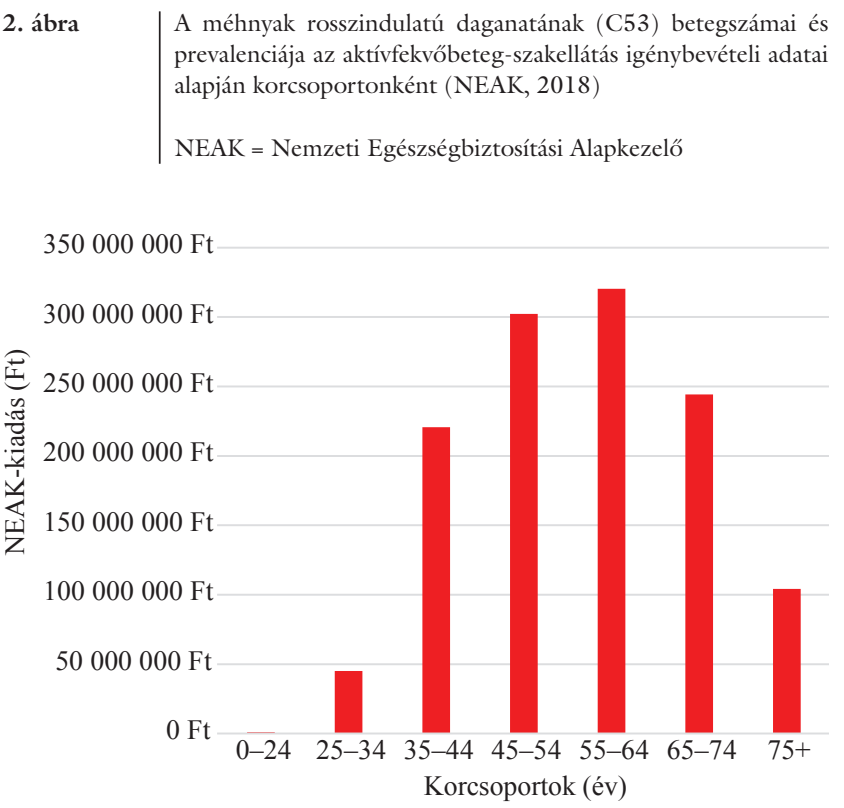

3. ábra

A méhnyak rosszindulatú daganatának (C53) összes egészségbiztosítási kiadása korcsoportos bontásban (NEAK, 2018)

NEAK = Nemzeti Egészségbiztosítási Alapkezelő

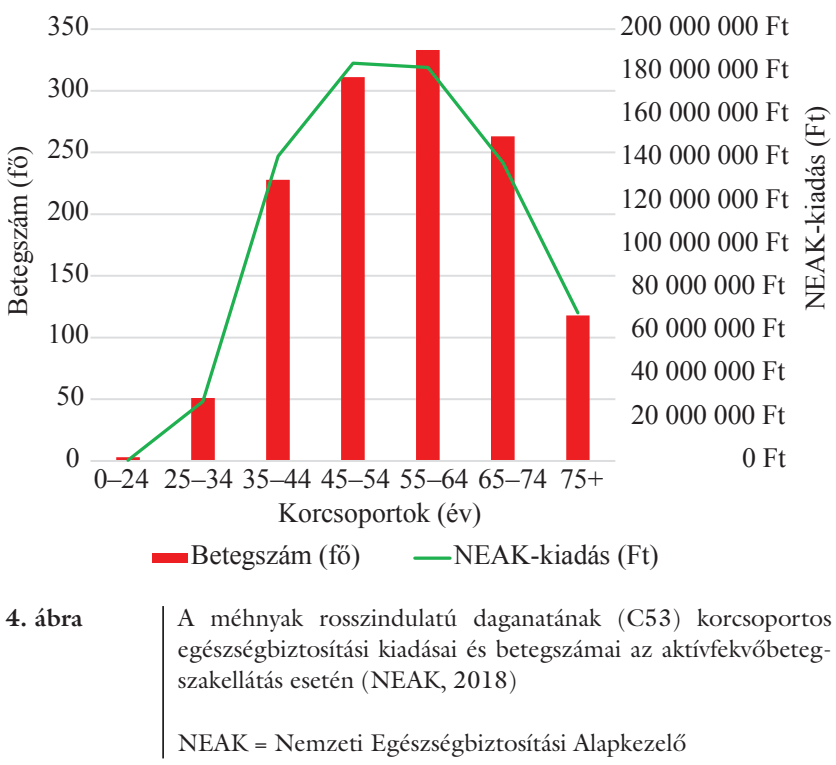

adási tételt az egészségbiztosító számára mindhárom betegségcsoport esetén, kiemelten a rosszindulatú daganat kapcsán (742,3 millió Ft). Az 55-64 éves korcsoportra esik a legmagasabb betegszám és kiadás egyaránt. Ezt követi a 45-54 éves, majd a 65-74 éves korcsoport. A betegszámok és a kiadások jól korrelálnak egymással.

\section{Megbeszélés}

Az elemzés célja a méhnyakdaganatok betegségterhének meghatározása volt 2018-ra vonatkozóan. Ennek alapján a betegség legmagasabb prevalenciája a járóbetegszakellátás kapcsán jelentkezett, az igénybevétel adatai alapján 102 beteg/100 000 lakos. A NEAK 2018-ban összesen 1,276 milliárd Ft-ot költött a méhnyakdaganatok kezelésére, ami 4,7 millió USD-nak, illetve 4,0 millió EUR-nak felel meg. Ellátási típusonként vizsgálva a legnagyobb kiadási tétel az aktívfekvőbeteg-szakellátásban jelenik meg, éves szinten 763,9 millió Ft (59,9\%). Ezt követi a CT/MRI (232,9 millió Ft; 18,3\%), a járóbetegszakellátás (86,3 millió Ft; 6,8\%) és a gyógyszer-ártámogatások (85,8 millió Ft; 6,7\%) költsége. Az aktívfekvőbeteg-szakellátás kiemelkedő aránya az összes egészségbiztosítási kiadás arányában a méhnyakdaganatok kezelési lehetőségeihez kapcsolódik [27, 28]. A daganatok típusa szerinti sorrendben a méhnyak rosszindulatú daganatához (C53) kapcsolódtak a legmagasabb kiadások.

A szervezett lakossági szúróvizsgálatok speciális helyet foglalnak el a hazai egészségpolitika történetében. Az egészség-gazdaságtan területén a vastagbél-, az emlő- és a méhnyakszűrés bevezetése kapcsán készített költséghatékonysági számítások [29-31] voltak az egykori Országos Egészségbiztosítási Pénztár történetében az első egészség-gazdaságtani számítások, amelyek a döntéshozatalt megelőzően készültek [32-36]. Rendelkezünk továbbá betegségteher-vizsgálattal is ugyanezen időszakból [17], így összehasonlíthatóvá váltak a 2001., 2014. évi és a méhnyakdaganatok kapcsán a 2018. évi egészségbiztosítási kiadások [37]. Eszerint a magyarországi egészségbiztosítási betegségteher elemzésének eredményei azt mutatják, hogy míg a colorectalis, illetve az emlődaganatok éves egészségbiztosítási kiadásai 2001 óta jelentős mértékben, 125\%-kal, illetve 155\%-kal emelkedtek, addig a méhnyakdaganatok esetében nem látunk ilyen emelkedést. A költségei mindössze minimális mértékben, a 2001. évi 1,042 milliárd Ft-ról 2014-re 1,053 milliárd Ft-ra, vagyis 1\%-kal, míg 2018-ra 1,276 milliárd Ft-ra, 21\%-kal nőttek.

Brazíliában a méhnyak rosszindulatú daganata megelőzésének és kezelésének becsült összköltsége társadalmi szempontból 1321683034 USD volt, amely a következő kategóriákba sorolt költségekből tevődött össze: orvosi eljárások (213 199490 USD), orvos-beteg találkozások (vizit) (325 509842 USD), betegszállítás (106 521537 USD) és termelékenységi veszteség (676 452166 USD). A közvetett költségek az összes költség 51\%-át tették ki, ezt a közvetlen orvosi költségek 
(orvos-beteg találkozások és orvosi eljárások) követték 41\%-kal és a közvetlen nem egészségügyi költségek (betegszállítással) 8\%-kal. Az összes kiadás 46\%-a az állami rendszert, 54\%-a pedig a magánrendszert terhelte [38]. Ehhez képest egy amerikai tanulmány adatai szerint a nőgyógyászati daganatoknak tulajdonított éves orvosi kiadások körülbelül 3,8 milliárd USD-t tettek ki, a betegenkénti átlagos éves költség 6293 dollár volt. A nőgyógyászati daganatos betegek nyolcéves medián költsége 492,6 dollár volt. A betegségek között a méhtestdaganat volt a legdrágább, ezt követte a petefészek és a méhnyak rosszindulatú daganata. A nógyógyászati daganatok éves orvosi kiadásainak több mint fele a fekvőbeteg-ellátásnak volt betudható (53\%; 2,03 milliárd USD) [39].

Marokkóban a Nemzeti Onkológiai Intézet adatai szerint 2006-ban 550 beteget kezeltek rosszindulatú méhnyakdaganattal, amelynek költsége 1429673 USD volt; az átlagot $2599 \pm 839$ USD-ra becsülték. A kezelések között a sugárkezelések és a mütétek az összes költség 94\%-át tették ki. Az egyéb ellátások (laboratóriumi vizsgálatok és konzultációk) csak a maradék 6\%-át jelentették a költségeknek. A betegek kezelésének összköltsége jelentősen függött a daganat stádiumától, azzal együtt csökkent $(\mathrm{r}=-0,491, \mathrm{p}<0,001)$ [40].

Lengyelországban 2012-ben a rosszindulatú méhnyakdaganattal kezelt esetek száma 33482 volt. Az invazív méhnyakdaganatos betegek kezelésével kapcsolatos összes költség elérte az 52377006 PLN-t. A sugárterápia és az azzal összefüggő kórházi ellátás költségei (39,0\%) és a mútéti költségek $(37,3 \%)$ voltak a legmagasabbak itt is 2012-ben. Az összes költségnek mindössze a 0,1\%-át költötték rehabilitációra [41].

Az elemzés korlátai között meg kell említeni az adatbázis alkalmazásához kapcsolódó elemeket, mint azok validitása vagy teljessége. Ugyanakkor a NEAK-adatokon kívül más adatbázis hiányában országos lefedettségú elemzés elvégzésére nem lett volna lehetőségünk.

Tekintve, hogy a tanulmányunkban vizsgált betegség szưréssel megelőzhető, hosszú távon megfontolandó annak értékelése a finanszírozó számára, hogy a bizonyítottan hatékony szûrési módszerek alkalmazása hogyan segítené a kórképek korai felismerését és ezáltal hatékony kezelését [42]. A folyadékalapú citológia és a HPVDNS-teszt nagyobb érzékenységgel, de alacsonyabb specificitással rendelkezik, mint a Pap-teszt, ami mind a valódi pozitív, mind az álpozitív esetek fokozott nyomon követését és további vizsgálatok elvégzését teszi szükségessé [43]. Egy svéd költséghatékonysági vizsgálat öszszevetette a hagyományos citológiai szűrést, a 35 éves korig tartó hagyományos vizsgálatot HR-HPV-önmintavétellel kiegészített, úgynevezett kombinált szûréssel, amelynek eredménye szerint az ötévente végzett kombinált teszt költséghatékonyabb a hagyományos eljárásnál; az egy megnyert életévre jutó költségnövekmény 80000 EUR [44].

A méhnyak rosszindulatú daganatának megelőzése érdekében hozott intézkedések több országban változnak, a HPV elleni védőoltás és a HPV-DNS-teszt szúrési protokollba történő beépítésének köszönhetően. Ennek ellenére a tapasztalatok azt mutatják, hogy a szürésen való részvételi arány évről évre csökken. Ezek a tényezők kihívást, ugyanakkor lehetőségeket is teremtenek a döntéshozók és az alapellátásban dolgozók számára [45]. Hazánkban a szervezett méhnyakszürés korszerüsítésének, lehetőségeinek értékeléséhez sok szempontot figyelembe vevő, többek között a várható költségekre vonatkozó elemzések szükségesek, ennek bemutatására a jelen vizsgálatunk nem terjedt ki. Ugyanakkor az új szúrési stratégiát megfelelő NEAK-finanszírozási támogatással célszerû bevezetni, a szűrővizsgálatoknak, a hozzájuk kapcsolódó további diagnosztikus kivizsgálásnak és terápiának a teljesítményvolumen-korlát alóli mentesítésével $[46,47]$.

Anyagi támogatás: A kézirat az „EFOP-3.6.2-16-201700009: Klinikai kutatások tematikus hálózatának kialakítása és nemzetköziesítése” pályázat és a „Nemzeti laboratóriumok létrehozása 2020 program: Humán reprodukciós nemzeti laboratórium” projekt támogatásával készült.

Szerzői munkamegosztás: A vizsgálat tervezése és lefolytatása: M.-V. R., E. D., B. I. Adatok gyújtése és ellenőrzése: M.-V. R., E. D., B. I. Adatfeldolgozás és adatelemzés: M.-V. R., K. L. F., K. Zs., Cs. T., E. D., N. N. Statisztikai elemzések: M.-V. R., K. Zs., Cs. T. Az eredmények értelmezése: M.-V. R., B. I., B. J., K. Zs. Irodalomkutatás: K. Zs., Cs. T., E. D., N. N., P.-K. D., B. J. A kézirat megszövegezése: M.-V. R., K. L. F., K. Zs., E. D., Cs. T., N. N., P.-K. D., B. I., B. J. A cikk végleges változatát valamennyi szerzó elolvasta és jóváhagyta.

Érdekeltségek: A szerzőknek nincsenek érdekeltségeik.

\section{Köszönetnyilvánítás}

A szerzők köszönetet mondanak az „EFOP-3.6.2-16-2017-00009: Klinikai kutatások tematikus hálózatának kialakítása és nemzetköziesítése” pályázat és a „Nemzeti laboratóriumok létrehozása 2020 program: Humán reprodukciós nemzeti laboratórium” projekt támogatásáért.

\section{Irodalom}

[1] Mezei AK, Armstrong HL, Pedersen HN, et al. Cost-effectiveness of cervical cancer screening methods in low- and middleincome countries: a systematic review. Int J Cancer 2017; 141: 437-446.

[2] Bray F, Ferlay J, Soerjomataram I, et al. Global cancer statistics 2018: GLOBOCAN estimates of incidence and mortality worldwide for 36 cancers in 185 countries. CA Cancer J Clin. 2018; 68: $394-424$.

[3] Arbyn M, Weiderpass E, Bruni L, et al. Estimates of incidence and mortality of cervical cancer in 2018: a worldwide analysis. Lancet Glob Health 2020; 8: e191-e203. 
[4] Wojtyla C, Janik-Koncewicz K, La Vecchia C. Cervical cancer mortality in young adult European women. Eur J Cancer 2020; 126: 56-64.

[5] Polman NJ, Snijders PJ, Kenter GG, et al. HPV-based cervical screening: rationale, expectations and future perspectives of the new Dutch screening programme. Prev Med. 2019; 119: 108117.

[6] World Health Organization. Global strategy towards eliminating cervical cancer as a public health problem. Draft. Geneva, 16 December 2019. Available from: https://www.who.int/docs/ default-source/cervical-cancer/cerv-cancer-elimn-strategy16dec-12pm.pdf [accessed: January 4, 2021].

[7] Canfell K. Towards the global elimination of cervical cancer Papillomavirus Res. 2019; 8: 100170.

[8] von Karsa L, Arbyn M, de Vuyst H. European guidelines for quality assurance in cervical cancer screening. Summary of the supplements on HPV screening and vaccination. Papillomavirus Res. $2015 ; 1$ : 22-31.

[9] Wentzensen N. Triage of HPV-positive women in cervical cancer screening. Lancet Oncol. 2013; 14: 107-109.

[10] Huh WK, Ault KA, Chelmow D, et al. Use of primary high-risk human papillomavirus testing for cervical cancer screening: interim clinical guidance. Gynecol Oncol. 2015; 136: 178-182.

[11] Cuschieri K, Ronco G, Lorincz A, et al. Eurogin roadmap 2017: triage strategies for the management of HPV-positive women in cervical screening programs. Int J Cancer 2018; 143: 735-745.

[12] Póka R. Cervical screening. International overview and proposal for the development of domestic guidelines. [Méhnyakszúrés. Nemzetközi körkép és javaslat a hazai irányelvek fejlesztésére.] Magy Nőorv L. 2018; 81: 38-46. [Hungarian]

[13] Kovács A, Döbrőssy L, Budai A, et al. Cervical screening in Hungary: why does the "English model" work but the "Hungarian model" does not? Eur J Gynaecol Oncol. 2008; 29: 5-9.

[14] Boncz I, Sebestyén A, Ember I. Organized, nationwide cervical cancer screening programme in Hungary. Gynecol Oncol. 2007; 106: 272-273.

[15] Boncz I, Vajda R, Ágoston I, et al. Changes in the health status of the population of Central and Eastern European countries between 1990 and 2010. Eur J Health Econ. 2014; 15(Suppl 1): 137-141.

[16] Boncz I, Sebestyén A. A comparative analysis of the costs of treating breast, cervical, and colorectal cancer. [Az emlö-, méhnyak- és colorectalis daganatok kezelési költségeinek összehasonlító elemzése.] IME Interdiszciplináris Magyar Egészségügy 2005; 4(10): 16-19. [Hungarian]

[17] Boncz I. Prevention of cervical cancer in low-resource settings. JAMA 2006; 295: 1248-1249.

[18] Papp Z. Cervical tumors. In: Papp Z. (ed.) The textbook of obstetrics and gynecology. [A méhnyak daganatai. In: Papp Z. (szerk.) A szülészet-nőgyógyászat tankönyve.] Semmelweis Kiadó, Budapest, 2007; pp. 480-492. [Hungarian]

[19] Boncz I, Evetovits T, Dózsa Cs, et al. The Hungarian Care Managing Organization Pilot Program. Value Health Reg Issues $2015 ; 7: 27-33$

[20] Varga V, Boncz I, Sebestyén A, et al. Utilization indicators of balneotherapy in Hungary. [A gyógyfürdőellátások igénybevételi mutatói Magyarországon.] Orv Hetil. 2019; 160(Suppl 1): 2228. [Hungarian]

[21] Hornyák L, Nagy Z, Ilku L, et al. Price competition and reimbursement of biosimilar granulocyte-colony stimulating factor in Hungary. Expert Rev Pharmacoecon Outcomes Res. 2019; 19: 725-731.

[22] Boncz I, Sebestyén A. Financial deficits in the health services of the UK and Hungary. Lancet 2006; 368: 917-918.

[23] Eisingerné Balassa B, Csákvári T, Ágoston I. Health insurance pharmaceutical expenditures in Hungary. [Az egészségbiztosítási gyógyszerkiadások alakulása Magyarországon.] Orv Hetil. 2019; 160(Suppl 1): 49-54. [Hungarian]

[24] Péter I, Jagicza A, Ajtay Z, et al. Balneotherapy in psoriasis rehabilitation. In Vivo 2017; 31: 1163-1168.

[25] Boncz I, Kaló Z, Mohamed Ibrahim MI, et al. Further steps in the development of pharmacoeconomics, outcomes research, and health technology assessment in Central and Eastern Europe, Western Asia, and Africa. Value Health Reg Issues 2013; 2: 169170.

[26] Boncz I, Nagy J, Sebestyén A, et al. Financing of health care services in Hungary. Eur J Health Econ. 2004; 5: 252-258.

[27] Szánthó A, Demeter A, Papp Z. Management of cervical cancer patients in Hungary. [A méhnyakrákos betegek kezelése hazánkban.] Orv Hetil. 1994; 135: 1179-1182. [Hungarian]

[28] Papp Z, Csapó Zs, Mayer Á, et al. Wertheim-operation: 5-year survival of 501 consecutive patients with cervical cancer. [Wertheim-mútét: 501 operált méhnyakrákos beteg ötéves túlélési adatai.] Orv Hetil. 2006; 147: 537-545. [Hungarian]

[29] Boncz I, Sebestyén A, Pál M, et al. Health economics analysis of cervical cancer screening. [A méhnyakrákszűrések egészség-gazdaságtani elemzése.] Orv Hetil. 2003; 144: 713-717. [Hungarian]

[30] Boncz I, Sebestyén A, Dózsa Cs, et al. Health economics analysis of colorectal cancer screenings. [A colorectalis szürések egészség-gazdaságtani elemzése.] Magy Onkol. 2004; 48: 111-115. [Hungarian]

[31] Boncz I, Sebestyén A, Gulácsi L, et al. Health economics analysis of breast cancer screening. [Az emlőrákszürések egészség-gazdaságtani elemzése.] Magy Onkol. 2003; 47: 149-154. [Hungarian]

[32] Boncz I, Sebestyén A, Döbrőssy L, et al. The role of immunochemical testing for colorectal cancer. Lancet Oncol. 2006; 7: 363-364.

[33] Boncz I, Sebestyén A, Döbrőssy L, et al. The organisation and results of first screening round of the Hungarian nationwide organised breast cancer screening programme. Ann Oncol. 2007; 18: 795-799.

[34] Boncz I, Sebestyén A, Pintér I, et al. Age-group specific gap between treatment cost of and mortality due to breast and colorectal cancer. J Clin Oncol. 2007; 25: 4501-4502.

[35] Boncz I, Sebestyén A, Pintér I, et al. The effect of an organized, nationwide breast cancer screening programme on non-organized mammography activities. J Med Screen. 2008; 15: 14-17.

[36] Oberfrank F. The role of the National Health Insurance Fund administration in the development of health economics and health technology assessment in Hungary. Value Health Reg Issues 2014; 4: 6-7.

[37] Vajda R, Pakai A, Endrei D, et al. Examination of health insurance disease burden of cervical cancer in Hungary: a real world study. Value Health 2019; 22(Suppl 2): S66-S67.

[38] Novaes HM, Itria A, Silva GA, et al. Annual national direct and indirect cost estimates of the prevention and treatment of cervical cancer in Brazil. Clinics (Sao Paulo) 2015; 70: 289-295.

[39] Yue X, Pruemer JM, Hincapie AL, et al. Economic burden and treatment patterns of gynecologic cancers in the United States: evidence from the Medical Expenditure Panel Survey 20072014. J Gynecol Oncol. 2020; 31: e52.

[40] Cheikh A, El Majjaoui S, Ismaili N, et al. Evaluation of the cost of cervical cancer at the National Institute of Oncology, Rabat. Pan Afr Med J. 2016; 23: 209.

[41] Nowakowski A, Śliwczyński A, Seroczyński P, et al. Reimbursed costs of management of uterine cervical lesions in Poland. A descriptive analysis of data from the National Health Fund and the Ministry of Health. Cent Eur J Public Health 2016; 24: 163168.

[42] Koiss R, Boncz I, Hernádi Z, et al. Proposal for the modernization of cervical screening procedure in Hungary. [Javaslat a hazai 
méhnyakszûrési eljárásrend korszerúsítésére.] Orv Hetil. 2017; 158: 2062-2067. [Hungarian]

[43] Chuck A. Cost-effectiveness of 21 alternative cervical cancer screening srategies. Value Health 2010; 13: 169-179.

[44] Östensson E, Hellström AC, Hellman K, et al. Projected costeffectiveness of repeat high-risk human papillomavirus testing using self-collected vaginal samples in the Swedish cervical cancer screening program. Acta Obstet Gynecol Scand. 2013; 92: 830-840.

[45] Marlow L, Waller J. The changing landscape of cervical screening - what does the future hold for primary care? Eur J Cancer Care (Engl). 2017; 26: el2693.
[46] Endrei D, Zemplényi A, Molics B, et al. The effect of performance-volume limit on the DRG based acute care hospital financing in Hungary. Health Policy 2014; 115: 152-156.

[47] Endrei D, Molics B, Ágoston I. Multicriteria decision analysis in the reimbursement of new medical technologies: real-world experiences from Hungary. Value Health 2014; 17: 487-489.

(Mihály-Vajda Réka dr., Pécs, Vörösmarty u. 3., 7621 e-mail: reka.vajda@etk.pte.hu)

A cikk a Creative Commons Attribution 4.0 International License (https://creativecommons.org/licenses/by/4.0/) feltételei szerint publikált Open Access közlemény, melynek szellemében a cikk bármilyen médiumban szabadon felhasználható, megosztható és újraközölhető, feltéve, hogy az eredeti szerző és a közlés helye, illetve a CC License linkje és az esetlegesen végrehajtott módosítások feltüntetésre kerülnek. (SID_1) 